\title{
Comparative study of masticatory muscles in the goose (Anser anser domesticus) and the long-legged buzzard (Buteo rufinus) ${ }^{*}$
}

\author{
Burcu ONUK, Murat KABAK \\ Department of Anatomy, Faculty of Veterinary Medicine, University of Ondokuz Mayıs, Samsun-Turkey.
}

\begin{abstract}
Summary: In this study, six adult long-legged buzzards (Buteo rufinus) weighing 1000-1200 g and five adult geese (Anser anser domesticus) weighing 4500-5000 g with different feeding patterns were used. Goose has eight masticatory muscles named as $\mathrm{m}$. adductor mandibula externus, $\mathrm{m}$. adductor ossis quadrati, $\mathrm{m}$. depressor mandibula, $\mathrm{m}$. pterygoideus, m. pseudotemporalis profundus, m. pseudotemporalis superficialis, $\mathrm{m}$. protractor pterygoidei and $\mathrm{m}$. protractor quadrati. Due to the absence of $\mathrm{m}$. pseudotemporalis profundus, long-legged buzzard has seven masticatory muscles. Differences has been detected between these species in means of some muscle's origo and insertio and their parts. In goose, m. adductor mandibula externus was formed from three parts, named as pars rostralis, pars ventralis and pars profunda, but in long-legged buzzard it is formed by two parts named as pars rostralis and pars profunda. While m. depressor mandibula was constituted from two parts in goose, the same muscle was observed as a single part in long-legged buzzard. Furthermore, in the goose, m. pterygoideus was detected as having three parts named as pars ventralis, pars intermedialis and pars dorsalis, but in long-legged buzzard it was formed by only one part which is thicker compared to the other masticatory muscles.
\end{abstract}

Key words: Anatomy, goose, long-legged buzzard, masticatory muscle

\section{Kaz (Anser anser domesticus) ve kızıl şahin'de (Buteo rufinus) çiğneme kaslarının karşılaştırmalı olarak incelenmesi}

Özet: Bu çalışmanın materyalini farklı beslenme alışkanlığına sahip 6 adet 1000-1200 gr ağırlığında kızıl şahin (Buteo rufinus) ile 5 adet 4500-5000 gr ağırlı̆̆ında ergin evcil kaz (Anser anser domesticus) oluşturdu. Çiğneme kasları kazda m. adductor mandibula externus, m. adductor ossis quadrati, m. depressor mandibula, m. pterygoideus, m. pseudotemporalis profundus, $\mathrm{m}$. pseudotemporalis superficialis, $\mathrm{m}$. protractor pterygoidei ve $\mathrm{m}$. protractor quadrati olmak üzere toplam sekiz adet, kızıl şahinde ise $\mathrm{m}$. pseudotemporalis profundus'un bulunmaması nedeniyle yedi adet olarak belirlendi. İncelenen türlerde bu kaslardan bazılarının parçaları ile origo ve insertiosunda da farklılıklar saptandı. Kazda m. adductor mandibula externus, pars rostralis, pars ventralis ve pars profunda olmak üzere üç parça iken kızıl şahinde pars rostralis ve pars profunda olmak üzere iki kısımdı. Musculus depressor mandibula kazda iki parçadan oluşurken kızıl şahin'de ise sadece bir parçaydı. Bunlardan başka m. pterygoideus, kazda pars ventralis, pars intermedialis ve pars dorsalis olmak üzere üç kısımdı. Fakat aynı kas kızıl şahin'de diğer kaslarıyla karşılaştırıldığında oldukça kalın olan tek parçalı bir kas olarak belirlendi.

Anahtar sözcükler: Anatomi, çiğneme kası, kaz, kızıl şahin

\section{Introduction}

Unlike mammals, birds can move their upper jaws vertically by using the joints called maxillopalatine apparatus (11). This movement is called as "cranial kinesis". The cranial kinesis, which is started by the related muscles around the joints and effects os quadratum, is transmitted to the upper jaw by os zygomaticum in lateral and by os pterygoid- palatinum complex in medial $(7,11)$. Thus, the upper jaw is lifted upwards. This vertical movement of the upper jaw with a synchronous movement of the lower jaw creates a wide opening between the beaks and this movement provides quite a convenience in food intake for the birds $(1,5,9$, $11,13)$

To this day, there have been a lot of studies in birds related to skull bones (12), development and morphology of masticatory muscles $(8,10,14)$, cranial morphology in feeding and drinking (7), and cranial kinesis (4). But, there has not been a comprehensive anatomic study in goose and long-legged buzzard related to the subject. By this study, it has been intended to compare the masticatory muscles of the long-legged buzzard (Buteo rufinus) which belongs to neognathae subclass of falconiformes order and the masticatory muscles of

\footnotetext{
This study was presented in XXVIII ${ }^{\text {th }}$ Congress of the European Association of Veterinary Anatomists, Paris and published as a summary in Anatomia Histologia Embryologia (Volume 39, Number 4, August 2010)
} 
domestic goose (Anser anser domesticus) which belongs to the neognathae subclass of anseriformes order, both of which have different feeding habits and thus assist to the researchers who are interested in this subject.

\section{Materials and Methods}

The materials of this study, which have also been used previously in other studies were six adult longlegged buzzards (Buteo rufinus, falconiformes order, neognathae subclass) weighing 1000-1200 g and five adult domestic geese (Anser anser domesticus, anseriformes order, neognathae subclass) weighing 4500$5000 \mathrm{~g}$ with different feeding patterns. There was not any problem with jaw-opening and jaw-closure in these materials. After the macro-anatomical findings of the masticatory muscles of goose and buzzard had been obtained, the photographs were taken using an Olympus C-5060 digital camera. Nomina Anatomica Avium (3) was used as nomenclature for anatomical terms.

\section{Results}

Masticatory muscles have been found to be eight in goose and seven in long-legged buzzard.

M. adductor mandibula externus: In goose, m. adductor mandibula externus (Figure 1,2) was determined to be composed of three parts as pars rostralis (Figure 1/a), pars ventralis (Figure $1 / \mathrm{b}$ ), and pars profunda (Figure 2/a). It was observed that pars rostralis originated from proc. zygomaticus and connected to the dorsal part of the mandibula. Pars ventralis of the same muscle originated from caudolateral of proc. zygomaticus and fossa temporalis and connected to the prominent in lateral of pars supraangularis of the mandibula. Pars profunda of $\mathrm{m}$. adductor mandibula externus originated from the ventral of pars squamosa of os temporale and attached to the lateral of pars intermedia of the mandibula. In long-legged buzzard, m. adductor mandibula externus (Figure 3, 4), had two parts called pars rostralis (Figure 3/a, 4/a), and pars profunda (Figure 4/a'). Of these, pars rostralis was observed to start from fossa temporalis directly under $\mathrm{m}$. cucularis capitis and to connect to angulus oris passing under lig. postorbitale. Pars profunda was observed to start from proc. oticus of os quadratum and to connect widely from proc. coronoideus to pars supraangularis of the mandibula.

M. adductor mandibula ossis quadrati: In goose, it was observed that $\mathrm{m}$. adductor mandibula ossis quadrati (Figure 1/c, 2/b), originated from the medial side of corpus of os quadratum and connected to proc. lateralis mandibula of the mandibula. In long-legged buzzard, the same muscle (Figure 3/b, 4/b, 5/c), originated widely throughout whole corpus of os quadratum and attached to the region between proc. coronoideus of mandibula and proc. lateralis mandibula.

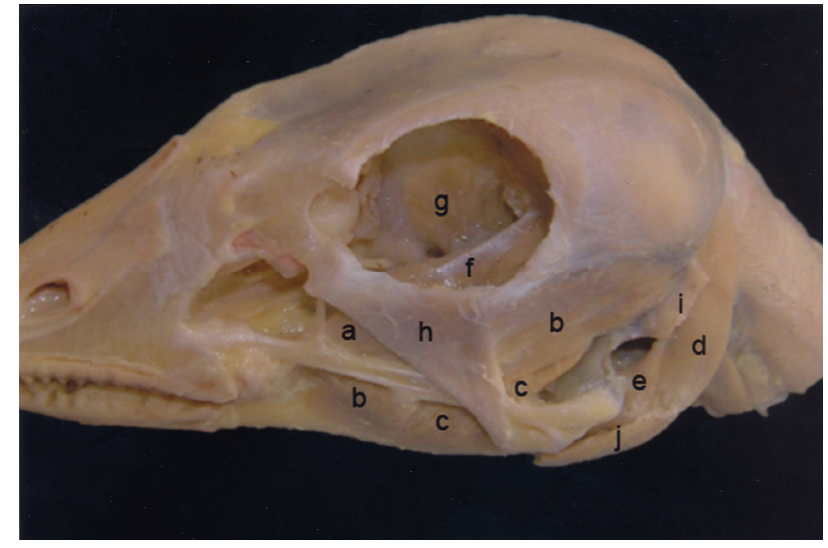

Fig. 1: Lateral view of the masticatory muscles in goose. a) rostral part of the $m$. adductor mandibula externus; $b$ ) ventral part of the $\mathrm{m}$. adductor mandibula externus; c) m. adductor mandibula ossis quadrati; d) the first part of the m. depressor mandibula; e) the second part of the $\mathrm{m}$. depressor mandibula; $\mathrm{f}$ ) m.pseudotemporalis superficialis; g) m. protractor pterygoidei; h) lig. suborbitale- lig. lacrimomandibulare-lig. postorbitale; i) m. cucularis capitis; j) m. stylohyoideus

Şekil 1: Kazda çiğneme kaslarının lateral görünümü

a) the $m$. adductor mandibula externus'un rostral parçasi; b) the $\mathrm{m}$. adductor mandibula externus'un ventral parçasi; c) $\mathrm{m}$. adductor mandibula ossis quadrati; d) $\mathrm{m}$. depressor mandibula'nın ilk parçası; e)m. depressor mandibula'nın ikinci parças1; f) m.pseudotemporalis superficialis; g) m. protractor pterygoidei; h) lig. suborbitale- lig. lacrimomandibulare-lig. postorbitale; i) m. cucularis capitis; j) m. stylohyoideus

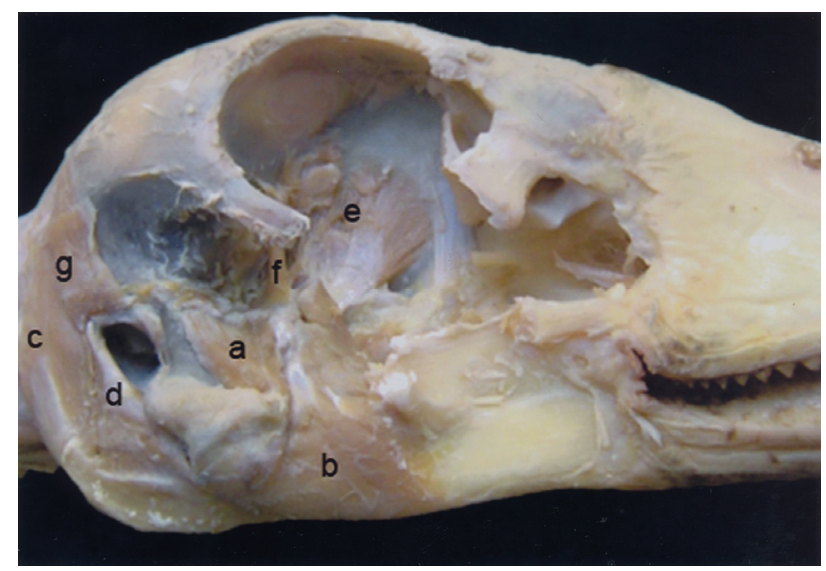

Fig. 2: Lateral view of the masticatory muscles in goose.

a) profund part of the $\mathrm{m}$. adductor mandibula externus; b) $\mathrm{m}$. adductor mandibula ossis quadrati; c) the first part of the $\mathrm{m}$. depressor mandibula; d) the second part of the $\mathrm{m}$. depressor mandibula; e) $\mathrm{m}$. protractor pterygoidei; f) $\mathrm{m}$. protractor quadrati; g) m. cucularis capitis

Şekil 2: Kazda çiğneme kaslarının lateral görünümü

a) $\mathrm{m}$. adductor mandibula externus'un profund parçasi; b) $\mathrm{m}$. adductor mandibula ossis quadrati; c) $\mathrm{m}$. depressor mandibula'nın ilk parçası; d) m. depressor mandibula'nın ikinci parças1; e) m. protractor pterygoidei; f) $\mathrm{m}$. protractor quadrati; g) m. cucularis capitis 


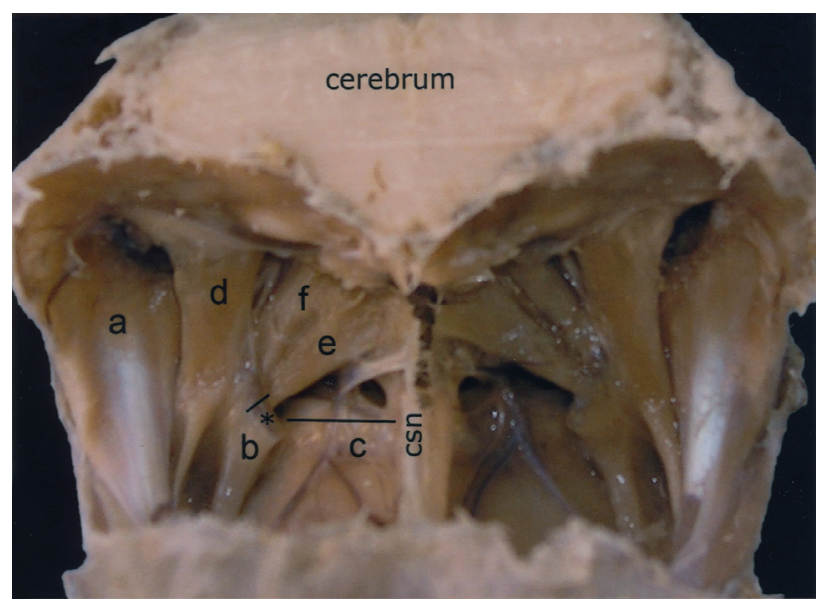

Fig.3: Horizontal view of the masticatory muscles in longlegged buzzard

a) rostral part of the $\mathrm{m}$. adductor mandibula externus; b) $\mathrm{m}$. adductor mandibula ossis quadrati; c) m. pterygoideus; d) $\mathrm{m}$. pseudotemporalis superficialis; e) $\mathrm{m}$. protractor pterygoidei; f) m. protractor quadrati; csn) cartilago septi nasi

Şekil 3: Kızıl şahinde çiğneme kaslarının horizontal görünümü a) $\mathrm{m}$. adductor mandibula externus'un rostral parçası; b) $\mathrm{m}$. adductor mandibula ossis quadrati; c) m. pterygoideus; d) $\mathrm{m}$. pseudotemporalis superficialis; e) $\mathrm{m}$. protractor pterygoidei; f) m. protractor quadrati; csn) cartilago septi nasi

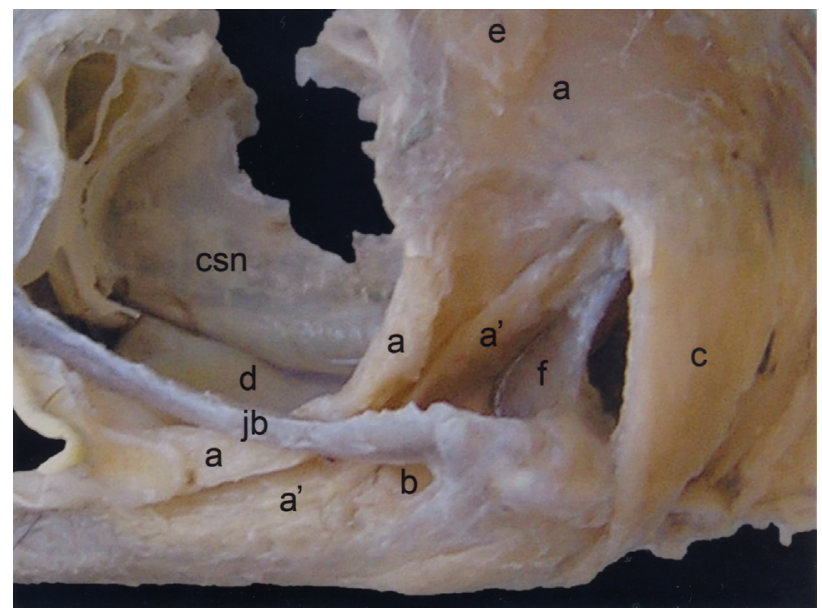

Fig. 4: Lateral view of the masticatory muscles in long-legged buzzard.

a) rostral part of the $\mathrm{m}$. adductor mandibula externus; a') profund part of the $\mathrm{m}$. adductor mandibula externus; b) $\mathrm{m}$. adductor mandibula ossis quadrati; c) m. depressor mandibula; d) m.pterygoideus; e) m. cucularis capitis; f) os quadratum; Jb) os jugale; csn) cartilago septi nasi

Şekil 4: Kızıl şahinde çiğneme kaslarının lateral görünümü

a) m. adductor mandibula externus'un rostral parçası; a') m. adductor mandibula externus'un profund parçasi; b) $\mathrm{m}$. adductor mandibula ossis quadrati; c) m. depressor mandibula; d) m.pterygoideus; e) m. cucularis capitis; f) os quadratum; Jb) os jugale; csn) cartilago septi nasi

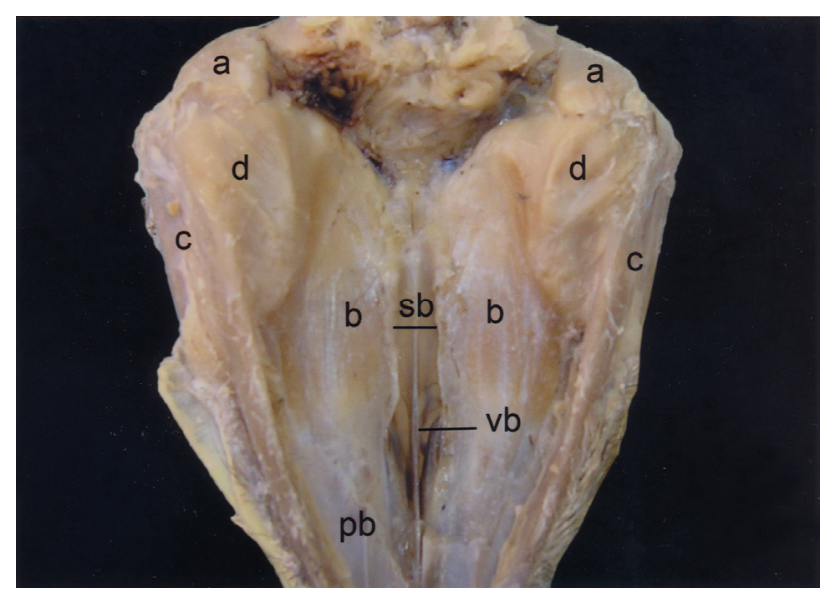

Fig. 5: Ventral view of the masticatory muscles in long-legged buzzard.

Şekil 5: Kızıl şahinde çiğneme kaslarının ventral görünümü a) m. depressor mandibula; b) m. pterygoideus; c) m. adductor mandibula ossis quadrati; d) $\mathrm{m}$. sepihyoideus; $\mathrm{sb}$ ) os sphenoidale; vb) os vomer; $\mathrm{pb}$ ) os palatinum

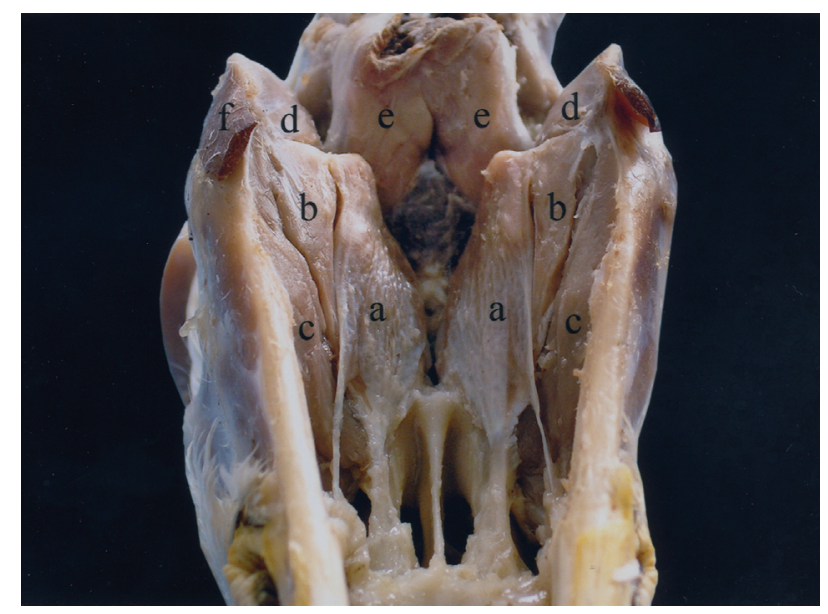

Fig. 6: Ventral view of the masticatory muscles in goose. Şekil 6: Kazda çiğneme kaslarının ventral görünümü a-b-c) m. pterygoideus; d) m. pseudotemporalis profundus; e) $\mathrm{m}$. sepihyoideus; f) $\mathrm{m}$. stylohyoideus

M. depressor mandibula: In goose, it has been determined that $\mathrm{m}$. depressor mandibula (Figure 1, 2), was composed of two parts. The first part (Figure 1/d, $2 / c$ ), was observed to start from crista nuchalis transversa of calvaria next to $\mathrm{m}$. complexus by passing under $\mathrm{m}$. cucularis capitis and to attach to proc. retroarticularis of pars caudalis of ramus mandibula in ventral. The second part (Figure 1/e, 2/d), a typical triangle-shape, got a thin origin from proc. paraoccipitalis of basis cranii externa and connected to the region between proc. lateralis mandibula and proc. retroarticularis in ventral. Musculus depressor mandibula (Figure 4/c, 5/a), in long-legged buzzard was observed to be a single muscle that originated from proc. paraoccipitalis of basis cranii externa and connected to proc. retroarticularis of the mandibula. 
M. pterygoideus: In goose, it was determined that m. pterygoideus (Figure 6), was composed of three parts as ventral (Figure 6/a), intermedial (Figure 6/b) and dorsal (Figure 6/c). The pars ventralis originated from two different points in cranial. One of these started from os palatinum and the other from maxilla as a thin tendon. It was identified that these two parts coalesced and connected to pars ventralis of os pterygoideum, proc. medialis mandibula and os sphenoidale in caudal. It was observed that the pars intermedialis which is in dorsolateral of pars ventralis of $\mathrm{m}$. pterygoideus, originated from os palatinum between two points, where the pars ventralis originated and ended in proc. medialis mandibula and ventral of ramus mandibula. Pars dorsalis which formed $\mathrm{m}$. pterygoideus and was in the deepest layer originated in ventrolateral of art. pterygopalatina and dorsal of os pterygoideum and filled this region by connecting to fossa aditus canalis mandibula. In longlegged buzzard, it was determined that $\mathrm{m}$. pterygoideus (Figure 3/c, 4/d, 5/b), originated from cranial of os palatinum as a single muscle and in a wider than the other muscles and connected ventro-laterally to the, dorsal of os pterygoideum and proc. retroarticularis of os angulare.

M. pseudotemporalis superficialis: In goose, it was observed that $\mathrm{m}$. pseudotemporalis superficialis (Figure $1 / \mathrm{f}$ ), which was in rostral of pars profunda of m. adductor mandibula externus originated from area muscularis aspera of os laterosphenoidale and connected to os supraangulare of mandibula. In long-legged buzzard, it (Figure 3/d) was determined that this muscle originated from rostral of fossa temporalis and connected to proc. coronoideus.

M. pseudotemporalis profundus: In goose, $\mathrm{m}$. pseudotemporalis profundus (Figure 6/d), which surrounded lig. mandibula occipitale, filled in between proc. medialis mandibula and proc. retroarticularis and connected to ostium canalis ophtalmici externi through the medioventral of pars dorsalis of $\mathrm{m}$. pterygoideus. In long-legged buzzard, this muscle was not found.

M. protractor pterygoidei: In goose, $\mathrm{m}$. protractor pterygoidei (Figure 1/g, 2/e), originated from interorbital septum and connected to os pterygoideum. Also it was seen that some fibers of this muscle connected to os quadratum. In long-legged buzzard, it was determined that the same muscle (Figure 3/e), originated from ventral of for. opticum and connected to os pterygoideum.

M. protractor quadrati: In goose, it was observed that $\mathrm{m}$. protractor quadrati (Figure $2 / \mathrm{f}$ ) originated from ventrolateral of for. opticum as a thin muscle bunch and connected to proc. orbitalis of os quadratum. In longlegged buzzard, it was determined that $\mathrm{m}$. protractor quadrati (Figure 3/f), which crossed $\mathrm{m}$. protractor pterygoidei in its dorsal, originated from ventral of for. opticum and connected to proc. orbitalis of os quadratum as a short muscle.

\section{Discussion}

Musculus adductor mandibula externus which is one of the masticatory muscles has been divided into four main parts as superficialis, medialis, profundus and posterior by George and Berger (6). Getty (5) was determined that the same muscle had divided into three parts as superficial, ventral and medial. Nickel et al (11) had not given any names while declaring that the same muscle has been formed by three main parts. Tokita (14) had mentioned that this muscle was divided into two parts as superficial and profund in parrot. In this study $\mathrm{m}$. adductor mandibula externus was composed of three parts in goose and two parts in long-legged buzzard. The origin and insertion of the m.adductor mandibula ossis quadrati (caudalis) in goose and long-legged buzzard was similar to that of described in the literature $(3,5,14)$.

Musculus pterygoideus was defined as two muscles by Holliday and Witmer ( 8 ) as m. pterygoideus dorsalis and $\mathrm{m}$. pterygoideus ventralis each having two parts as medial and lateral. In the study, m. pterygoideus was similar to the literature (8) in goose, but originated and ended as three seperate parts. The dorsal one was determined to be composed of two parts; medial and lateral. Also Holliday and Witmer (8) stated that $\mathrm{m}$. pterygoideus ventralis crosses throughout the ventral surface of os pterygoideum and close choana. This structure was not observed in goose. Same muscle in long-legged buzzard was observed to form from one muscle in accordance the report of Nickel et al (11).

Musculus depressor mandibula was determined to be composed of two parts in goose in accordance with literature $(2,3,6,11)$. There is no information regarding the exact boundaries of these parts in literature $(2,3,6)$, the boundaries of the muscle in goose was very distinct. The first part of $\mathrm{m}$. depressor mandibula, originated at crista nuchalis transversa of calvaria next to $\mathrm{m}$. complexus after crossing under $\mathrm{m}$. cucularis capitis and connected to proc. retroarticularis of ramus mandibula. The second part originated in a thin form from proc. paraoccipitalis of basis cranii externa and connected to the area between proc. lateralis mandibula and proc. retroarticularis. In long-legged buzzard, m. depressor mandibula was composed of a single part and this muscle started from proc. paraoccipitalis of ossa ottica as defined by Baumel et al (3).

Musculus pseudotemporalis superficialis, originating from area muscularis aspera of os laterosphenoidale and connecting to os supra-angulare of mandibula in goose, was similar to literature $(3,6)$. But it was determined that in long-legged buzzard, this muscle originated from rostral of fossa temporalis and connected to proc. coronoideus. 
Musculus pseudotemporalis profundus was defined by Nickel et al (11) to be a muscle that originate from proc. orbitalis of os quadratum and connect to the lateral face and dorsal edge of mandibula by fusing with $\mathrm{m}$. adductor mandibula posterior. In goose, this muscle that covered lig. mandibula occipitale filled between proc. medialis mandibula of the mandibula and proc. retroarticularis and connected to ostium canalis ophtalmici externi through medioventral of pars dorsalis of $\mathrm{m}$. pterygoideus. This muscle was absent in longlegged buzzard as in parrot (14)

It has been reported by Getty (5) that the muscle he mentioned as m. quadratopterygoidei, which is responsible for lifting the upper beak, originates from os orbitosphenoidale and basitemporal plate and connects to os quadratum and medial of os pterygoideum, respectively. Nickel et al (11), had only mentioned m. protractor quadrati as a muscle that originates from os sphenoidale and connects to proc. orbitalis of os quadratum. In Nomina (3), it was stated that since m. protractor pterygoidei and $\mathrm{m}$. protractor quadrati originated from septum interorbita, one muscle could have two parts. Tokita (14) has mentioned m. protractor pterygoidei, which originates from caudal of septum interorbitale and connects to os quadratum and a specific muscle which originated from rostral of septum interorbitale and connected to medial of mandibula in the parrot. In goose and long-legged buzzard, these muscles had two seperate origin and insertion points. But $\mathrm{m}$. protractor pterygoidei originated from interorbital septum in goose, and ventral of for. opticum in long-legged buzzard and connected to os pterygoideum. Musculus protractor quadrati originated from caudoventral of for. opticum as a thin muscle bunch in goose and originated from dorsal of $\mathrm{m}$. protractor pterygoidei in long-legged buzzard and connected to proc. orbitalis of os quadratum in both.

It was determined that the difference between longlegged buzzard and goose in that masticatory muscles having an important role in cranial kinesis, could be related to differences in feeding behaviour and this study presented a detailed data about the morphology of masticatory muscles in both species. As a result, muscle groups, working as the antagonist, of species studied were similar in size and parts.

\section{References}

1. Aspinall V, O'Reilly M (2004) Birds Introduction to Veterinary Anatomy and Physiology. Butterworth Heinemann. Edinburg. London. Toronto.

2. Bahadır A (2002) Hareket sistemi. 1-53. In: N Dursun (Ed), Evcil Kuşların Anatomisi. Medisan Publisher, Ankara.

3. Baumel JJ, King AS, Breazile JE, Evans HE, Vanden Berge JC (1993) Nomina Anatomica Avium. Cambridge, MA: Nuttall Ornithological Club.

4. Bout RG, Zweers GA (2001) The role of cranial kinesis in birds, Comp Biochem Physiol, 131, 197-205.

5. Getty R (1975) Sisson and Grossman's the Anatomy of the Domestic Animals. $5^{\text {th }}$ edn., WB Saunders Company. New York.

6. George JC, Berger AJ (1966) Avian Myology II. Head and Visceral Compartment of the Neck. Academic press, London.

7. Gussekloo SWS, Bout RG (2005) The kinematics of feeding and drinking in palaeognathous birds in relation to cranial morphology. J Exp Biol, 208, 3395-3407.

8. Holliday CM, Witmer LM (2007) Archosaur adductor chamber evolution: integration of musculoskeletal and topological criteria in jaw muscle homology. J Morphol, 268, 457-484.

9. King AS, McLelland J (1984) Birds: Their Structure and Function, $2^{\text {nd }}$ edn. London: Bailliere Tindall.

10. Meij MAA van der, Bout RG (2004) Scaling of jaw muscle size and maximal bite force in finches. J Exp Biol, 207, 2745-2753.

11. Nickel R, Schummer A, Seiferle E (1977) Anatomy of the Domestic Birds. Berlin-Hamburg: Verlag Paul Parey.

12. Orhan İO, Kabak M (2006) Facial bones of long-legged buzzard (Buteo rufinus) Anat Histol Embryol, 35, 211-216.

13. O'Malley B (2005) Clinical Anatomy and Physiology of Exotic Species, Structure and Function of Mammals, Birds, Reptiles, and Amphibians. $1^{\text {st }}$ edn., Elsevier Saunders, Toronto.

14. Tokita M (2004) Morphogenesis of parrot jaw muscles: Understanding the development of an evolutionary novelty. J Morphol. 259, 69-81.

Geliş tarihi: 29.11.2010 / Kabul tarihi: 24.03.2011

Address for correspondence:

Burcu Onuk

Department of Anatomy,

Faculty of Veterinary Medicine,

University of Ondokuz Mayis,

55139 Kurupelit, Samsun-TURKEY

e-mail: burcuonuk@omu.edu.tr 